\title{
ICP Analyses from the Cinnabar-Mercury Occurrence at Azogues (Loma Guashon), Ecuador: Ancient Industrial Uses and Human Health Implications
}

\author{
William E. Brooks \\ Geologist, Reston, VA 20191, USA \\ Email: webgeology@aim.com
}

How to cite this paper: Brooks, W. E. (2018). ICP Analyses from the Cinnabar-Mercury Occurrence at Azogues (Loma Guashon), Ecuador: Ancient Industrial Uses and Human Health Implications. Archaeological Discovery, 6, 38-51. https://doi.org/10.4236/ad.2018.61003

Received: November 28, 2017

Accepted: January 5, 2018

Published: January 8, 2018

Copyright $\odot 2018$ by author and Scientific Research Publishing Inc. This work is licensed under the Creative Commons Attribution International License (CC BY 4.0).

http://creativecommons.org/licenses/by/4.0/

\section{(c) (i) Open Access}

\begin{abstract}
ICP (Inductively Coupled Plasma) analyses of the Cretaceous marine sandstones at the Azogues (Loma Guashon), Ecuador cinnabar-mercury occurrence gave 11 - 113 ppm Hg. However, the ancient Azogues mines have been well documented previously, for example: 1) a 1799 hand drawn map "Plan del Cerro Mineral de Azogue" shows numerous adits; 2) during Colonial time, Cuenca founder, Gil Ramirez Davalos was owner of the mercury mines; 3) in the late 1800s, Teodoro Wolf described well-worked adits at Guashon and samples with $0.5 \% \mathrm{Hg}$; and more recently, 4) the Metallogenic Map of Ecuador shows the mercury occurrence at Azogues. Mineral resource assessment of the Azogues occurrence is important to regional archaeological studies of resource availability and ancient use of cinnabar as a pigment and as a source of mercury for gold amalgamation before the arrival of the Europeans, and possibly later, for silver amalgamation, during Colonial time.
\end{abstract}

\section{Keywords}

Gold, Mercury, Ecuador, Alluvial, Pre-Columbian

\section{Introduction}

Mercury and cinnabar occurrences are known throughout the Andes and blood-red cinnabar ( $\mathrm{HgS})$, the ore of mercury, was mined, selectively sorted, and ground for use as a pigment (vermilion), in funeral rituals, and as makeup during pre-contact time (Whitaker, 1941; Petersen, 1970/2010; Brown, 2001; Brooks et al., 2008). 
Alluvial gold was ancient man's main source of gold (Boyle, 1979), and Ecuador's rivers and streams were the likely sources of Ecuador's pre-Columbian gold and platinum (Petersen, 1970/2010; Cárdenas, 1990; Valdez et al., 2005; Carrión Mero et al., 2011; Lleres Peréz, 2015). For example, the Longroño placers, southeast of Cuenca, at the headwaters of the Rio Santa Bárbara, were identified as an alluvial gold source and the Laguna de Ayllon may contain fine-grained gold flakes washed from native chiefs during ancient rites (Yepez, 2016).

Mercury was used to amalgamate the millimeter-sized, and smaller, gold flakes (chispitas) found in these alluvial occurrences (Holloway, 1932; Delbridge \& Robertson, 1992; Báez, 2014) and elsewhere in the Andes before the arrival of the Europeans (Cabrera la Rosa, 1954; Kaufmann-Doig, 1978; Larco Hoyle, 2001; Brooks et al., 2013). Any gold nuggets, though rare, would have easily been removed from the gold pan (batea); however, the use of mercury is the only way to selectively remove the gold flakes from the ubiquitous "black sand" or heavy mineral concentrate (magnetite, cinnabar, zircon, rutile, and garnet) remaining in the gold pan. Small-scale gold mining, with mercury, of these fine-grained alluvial gold deposits continues to provide gold to Ecuador's modern mining economy (Gemuts, 1992; Sandoval, 2001; The Economist, 2013; Kiefer et al., 2015).

Regionally, Perú produced 16-22 metric tons of gold from small-scale alluvial gold mining, using mercury, during 2007-2011 (Gurmendi, 2012). And, as another example of the importance of mercury in alluvial gold mining, approximately 26,000,000 pounds (or 342,000 seventy-six pound flasks) of mercury were used during the California Gold Rush in 1849-50 (Alpers et al., 2005).

\section{Azogue and Mercury}

Azogue is a widely used synonym for mercury in the many small-scale alluvial gold mining areas throughout Latin America (Brooks, 2014). The word azogue, and variations, have been applied as toponyms, for example, Azogues, Ecuador, Azogines in Puno, Perú (Petersen, 1970/2010), and Azogani in Bolivia (Ahlfeld \& Schneider-Scherbina, 1964). Both azogue and cinnabar (zinjafir) have roots in the Arabic occupation of Spain and azogue was the name used for the silvery liquid metal that was produced from the world's oldest mercury mine, Almadén (al-Maden or The Mine, also Arabic in origin), in Spain (Bennett, 1948). Even now, in Latin America, Spanish mercury is preferred for small-scale gold mining and azogue, with its hint of Spanish origin and supposed higher quality, commands a higher price than recycled local mercury or mercury produced in the U.S. or elsewhere.

\section{Regional Mercury Occurrences}

Petersen (1970/2010) indicates that there are least 20 mercury occurrences in Perú, one of which is Azogines in Puno; however, the most well-known and important occurrence in the region is the Santa Barbara mercury mine, Huancavelica, Perú (Arana, 1901; Yates et al., 1955; Brown, 2001); however, Huancavelica mercury production stopped in 1975 (Roskill, 1990). In Bolivia, there 
are three mercury occurrences that include: 1) Mina María Paz, near a hill known as Azogani; 2) Mina El Triunfo, near Oruru; and 3) Mina Emilia, near Palca de Higuera (Barba, 1640/1923; Ahlfeld \& Schneider-Scherbina; 1964). There are numerous occurrences in Colombia (Singewald, 1950; Morer \& Nicholls, 1962; Hall \& Feininger, 1970; Mutis Jurado, 1983) and two of these, Aranzazu and an unnamed occurrence, in Quebrada Mico, near Aguadas, have recently been sampled (Brooks, 2014). The Quindio mercury mine, near Ibague, Dept. Tolima, Colombia may have been worked during ancient time and presumably also by the Europeans (Scheib, 1934; Singewald, 1950). Cinnabar occurrences in Chile have been documented by McAllister et al. (1950) and Ruiz Fuller (1965).

\section{Previous Work}

The cinnabar-mercury occurrence at Azogues, also referred to as Loma Guashon or Huashun, is approximately $4.5 \mathrm{~km}$ east of the town of Azogues (Azogues, 1968). And, even though several geologic references are readily available, the Azogues cinnabar occurrence was dismissed, without field study or thorough review of the literature, as a "red herring" in Andean mineral resource studies by Berger et al. (2016).

Previous work includes:

- A sketch map "Plan del Cerro Mineral de Azogue nombrado Guazun (Guashon)" that dates to 1799 shows the adits oriented along the north-south strike of the cinnabar vein (Archivo General de Indias, 1799) (Figure 1; Figure 2). Whether these mine workings date to Colonial time, or earlier with possible Colonial overprinting, has important implications for regional archaeological and mineral resource studies. Herein, these adits are interpreted to have initially been worked before the arrival of the Europeans. The evidence includes: 1 ) the numerous adits are shallow and follow the easy-access surface exposures of the cinnabar ore, and similarly, Petersen (1970/2010) indicates that pre-contact underground mining, such as interpreted at Azogues, seldom went for any depth and was typically limited by how far the sunlight could reach into the adit. The absence of mine waste near the entrance also indicates shallow workings. Early mines in Europe rarely penetrated more than $10 \mathrm{~m}$ (Craddock, 1995) and the Azogues adits, in comparison, may only reach $\sim 15 \mathrm{~m}$ (Table 1). Also see Figure 1 and note the presence of llumbreras (described in legend at lower left) that have been interpreted as smaller adits cut to the surface to serve as a light source; 2 ) there are no remnants of interior beams or supports; 3) pre-contact mining was typically limited to softer rocks such as the sandstones and shales (Figure 3) found at Azogues (Egüez, 1993a; 1993b); 4) ancient mines typically followed the veins and ore pockets, and not a compass direction, and therefore, were likely to be sinuous (Craddock, 1995); 5) the floors of ancient mines were seldom horizontal; and 6) the Azogues adits do not have the stone entrance 


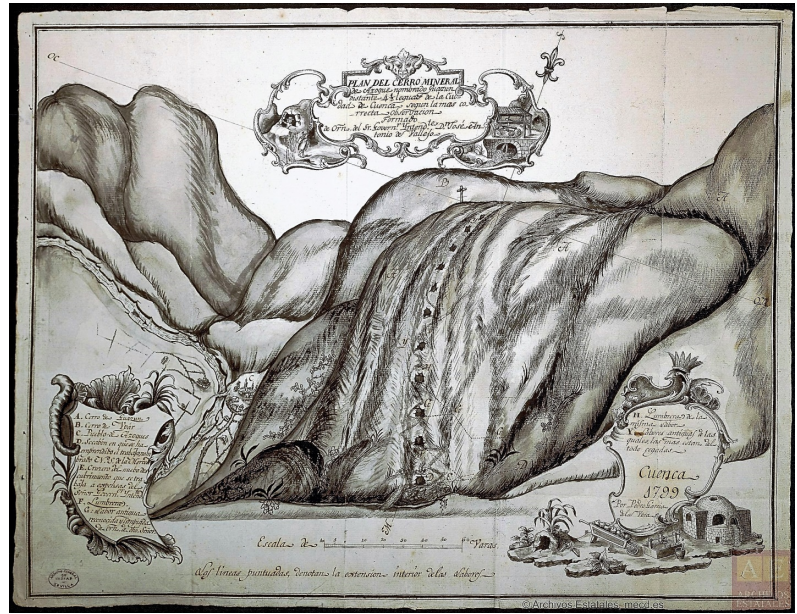

Figure 1. A sketch map of "Cerro Mineral de Azogue nombrado Guazun (Guashon)" that dates to 1799 showing adits oriented along the north-south strike of the cinnabar vein (Archivo General de Indias, 1799).

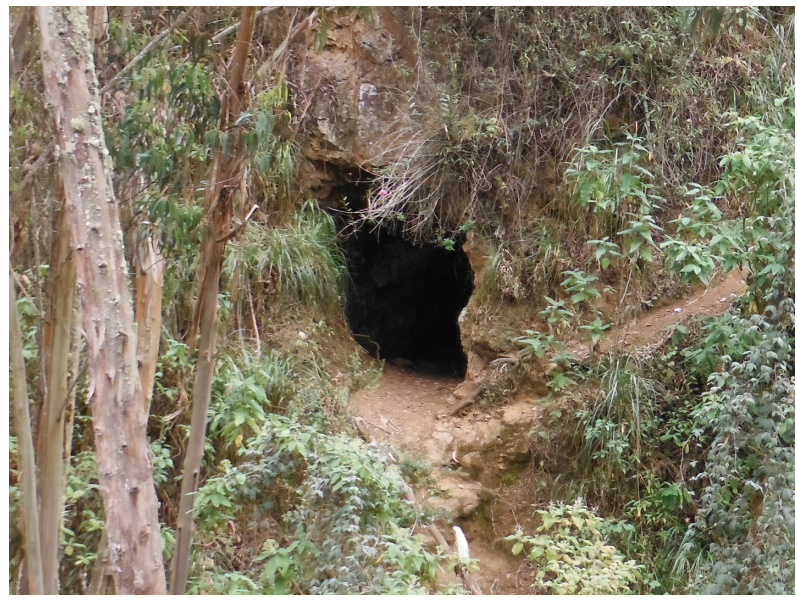

Figure 2. Lowest adit shown in Figure 1, note the absence of any entrance architecture.

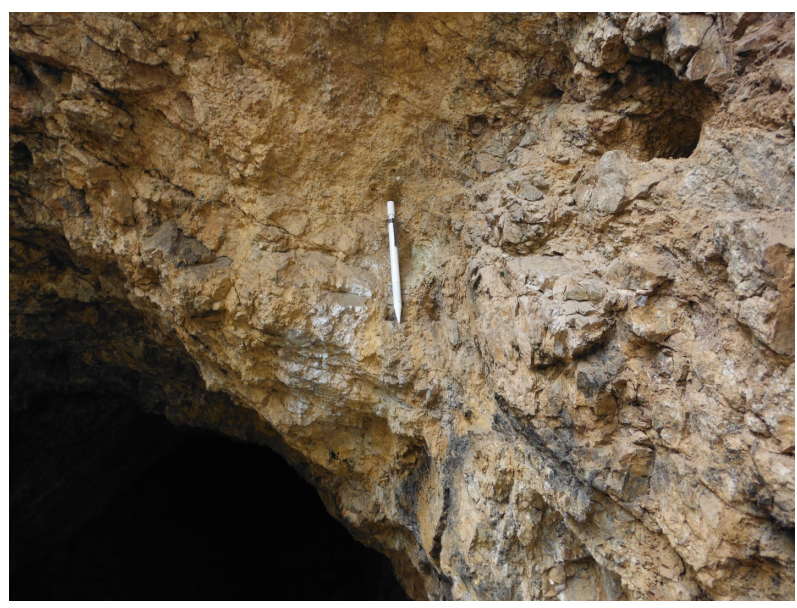

Figure 3. Sheared, altered sandstone at entrance to adit shown in Figure 2. 
Table 1. ICP analyses from the cinnabar-mercury occurrence at Azogues (Loma Guashon), Ecuador.

\begin{tabular}{|c|c|c|c|c|c|c|c|c|c|c|}
\hline & EC161a & EC161b & EC162a & EC162b & EC163 & EC164 & EC165 & EC166 & EC167 & TW61 \\
\hline $\mathrm{Au}(0.003)$ & 0.006 & 0.006 & 0.005 & 0.006 & 0.005 & 0.004 & na & 0.004 & na & 0.03 \\
\hline $\mathrm{Ag}(0.2)$ & 2.4 & 1.5 & 0.7 & 0.8 & 0.7 & 0.3 & 0.4 & 0.4 & 0.3 & - \\
\hline As $(2.0)$ & 75 & 45 & 46 & 43 & 19 & 9 & 8 & 14 & 4 & 1 \\
\hline $\mathrm{Ca}(1.0)$ & 23,067 & 1870 & 24,190 & 13,707 & 188,563 & 2243 & 11,342 & 229,571 & 5379 & 39,100 \\
\hline $\mathrm{Cu}(1.0)$ & 89 & 90 & 98 & 96 & 52 & 53 & 71 & 97 & 66 & - \\
\hline $\mathrm{Fe}(10)$ & 55,813 & 57171 & 65,646 & 78,533 & 55,718 & 15,762 & 42,341 & 52,120 & 32,532 & 9800 \\
\hline $\mathrm{Hg}(0.5)$ & 31.1 & 33.1 & 39.2 & 11.8 & 4.8 & 113.3 & 0.9 & 1.3 & $<1$ & 0.03 \\
\hline Mo (1.0) & 3 & 14 & 7 & 14 & 10 & $<1$ & $<1$ & $<1$ & $<1$ & 0.2 \\
\hline $\mathrm{Pb}(3.0)$ & 220 & 143 & 85 & 87 & 60 & 44 & 13 & 46 & 12 & 7 \\
\hline S (10) & 7262 & 878 & 741 & 417 & 270 & 182 & 289 & 180 & 276 & 240 \\
\hline $\mathrm{Sb}(0.3)$ & 54 & 34 & 22 & 21 & 15 & 10 & $<1$ & 12 & $<1$ & - \\
\hline U (8) & $<8$ & $<8$ & $<8$ & $<8$ & $<8$ & $<8$ & $<8$ & $<8$ & $<8$ & 0.45 \\
\hline $\mathrm{Zn}(1.0)$ & 371 & 263 & 249 & 228 & 132 & 70 & 105 & 112 & 117 & - \\
\hline
\end{tabular}

Multi-element ICP analyses (parts per million; detection limit given to right of element, in parentheses; nanot analyzed); American Assay, Sparks, NV, (SP0117075). Sample Descriptions: EC161a [741836/9696463 UTM] area sample inside lowest adit cut into NS striking vein, in rusty hematite altered sandstone, adit is $\sim 15 \mathrm{~m}$, entrance is $\sim 2.2 \mathrm{~m}$ by $1.9 \mathrm{~m}$, light comes in at the end of the adit from a stairstep-cut, steep $\sim 40^{\circ}$, llumbrera; quartz-biotite rhyolite in float. EC161b: [741836/9696463] spot sample at entrance, vertical shearing; EC162a: [741645/9696954] area sample $\sim 1-2 \mathrm{~m}$ within the steep $>40^{\circ}$, stairstep-cut llumbrera, $\sim 1.5 \times 2 \mathrm{~m}$, yellow alteration, jarosite? and hematite, following NS vein; EC162b: [741645/9696954] spot sample at entrance, vertical shearing; EC163: [741651/9696968] grab sample away from adit, minor quartz vein, limonite and hematite staining; EC164: [741615/9696928] south side of road, grab sample, on strike with NS vein and lowest adit, in road cut, quartz veins, white altered clay, rhyolite? EC165: [741343/9696968] soil sample, north side of road, from small terrace with broken tiles and wood; EC166: [741482/9696908] on terrace, sample of sandstone "float" with yellow stain, goethite/hematite, and cross-hatched, cm-sized, Fe-altered pattern; EC167: [741654/9696898] soil sample, dark, 3 - $4 \mathrm{~cm}$ deep, south side of road; TW61: Background distribution of elements in sandstone, in ppm; -, not available (Turekian \& Wedepohl, 1961).

architecture typical of mines that were exploited mainly during Colonial time, for example, the Santa Barbara mercury mine, Huancavelica, Perú (Figure 4(a), Figure 4(b)), or the La Candelaria silver mine, Potosí, Bolivia (Figure 4(c)).

- Chacon (1986) discussed Gil Ramirez Davalos' (governor of Quito and founder of Cuenca in 1557) Colonial ownership of the mercury mines at Cerro Azogue (Guashon); however, no data on mine production was included. Therefore, Azogues may have been a Colonial source of mercury, however, Azogues was a far smaller occurrence and less important than Huancavelica's mercury that was used for silver amalgamation during the late 1500s.

- Wolf (1892/1975) visited the Azogues area and documented “...old mercury mines in the Huaizhun (Guashon)... with large well-worked galleries... but not a drop of native mercury was found... it appeared that the occurrence 


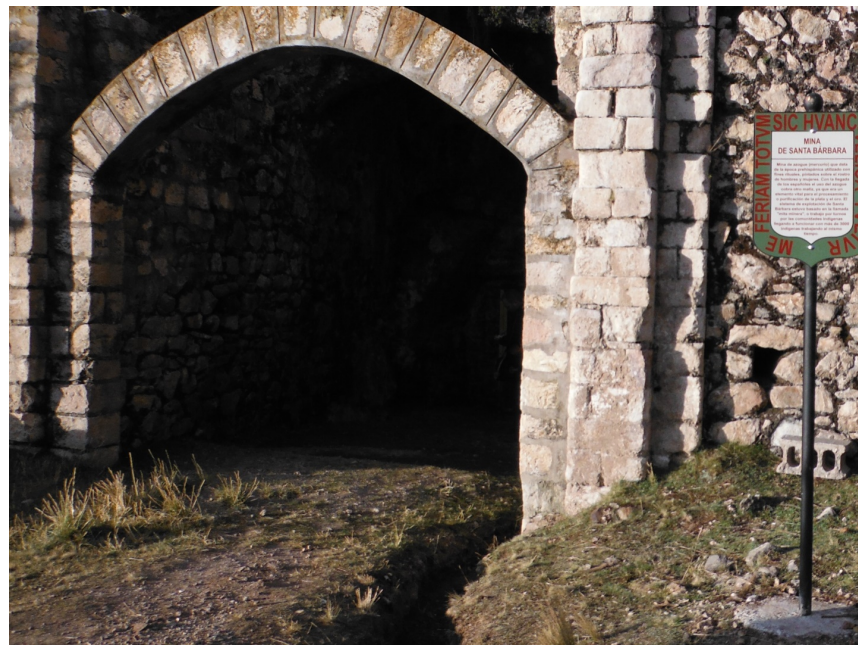

(a)

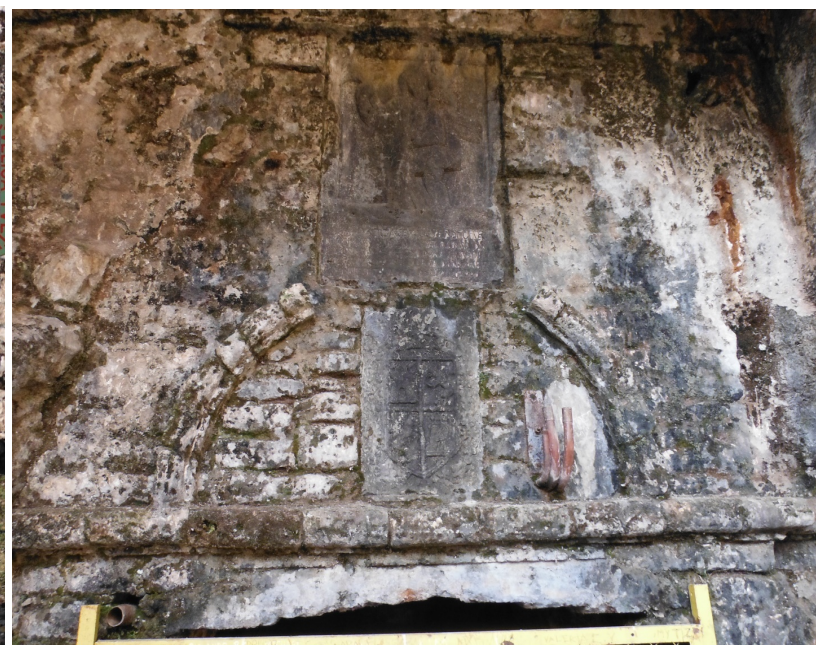

(c)

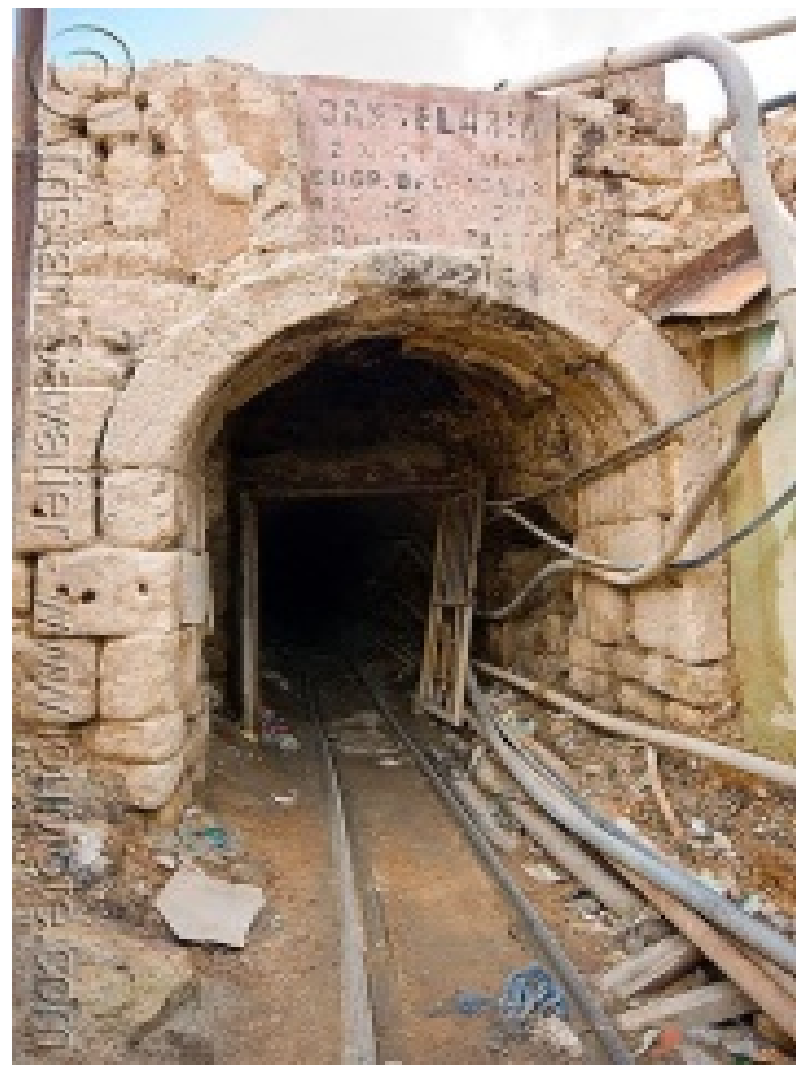

(c)

Figure 4. (a) Colonial stone architecture (interior and right of archway) at entrance to Santa Barbara mercury mine, Huancavelica, Perú; (b) Carved Spanish shield at entrance to Santa Barbara mercury mine, Huancavelica, Perú; (c) Colonial stone architecture, with modern mining equipment, at entrance to La Candelaria silver mine, Potosí, Bolivia (http://www.loupiote.com/photos/5043777416.shtml).

was completely exhausted... however; rock samples sent to Lima gave $1 / 2 \% \mathrm{Hg}$ (or $\sim 5000$ ppm Hg)." He also reported that campesinos (farm workers) near the mines found azogue in the soils and "...mercury droplets were found at Peñas de Guayaquil... at the foot of Cerro Santa Ana... in the Rio Guayas... 
and Rio Daule" and he suggested that the mercury was released during small-scale gold mining (pre-contact? or Colonial?) by lavaderos (small-scale gold miners) panning in the region.

- The Geologic Map of Ecuador (Egüez, 1993a) shows Cretaceous sandstones and other sedimentary rocks at Azogues and, most importantly, the companion Metallogenic Map of Ecuador (Egüez, 1993b) shows a mine symbol with the number 117 that corresponds to "Hg" in the accompanying list of Names and Details of Metallic Mines included on the map explanation. Delbridge \& Robertson (1992) also indicate that Azogues is the only mercury occurrence in Ecuador; however, two other occurrences, Cerro de Camachurco and San Jacinto, are referenced by Chacon (1986) and Vetter Parodi (2016). Other mercury occurrences spatially associated with Ecuador's epithermal porphyry gold-copper systems (Gemuts, 1992; Howell International, 2014) may have been overprinted or removed by recent mining.

- Truhan et al. (2005) researched "...the site of the Colonial, and possibly pre-Columbian, Azogues mines that were found near the municipality of Luis Cordero at Loma Huashún and ancient mining evidence included reddened scoria."

\section{ICP Data from Azogues}

As noted by Wolf (1892/1975) the Azogues mines had been exhausted of their native mercury; however, rock samples sent to Lima contained $5000 \mathrm{ppm} \mathrm{Hg}$. Therefore, mercury occurrences such as Azogues should be evaluated using modern geochemical methods to document the ore that was produced.

Using the basic tools of mineral resource assessment that include a site visit and geochemical sampling (Inductively Coupled Plasma), the altered sandstones in the adits at Azogues gave 11.8 - 113.3 ppm Hg (Table 1), which is consistent with mining that would have long since removed the high-grade cinnabar ore and native mercury leaving only trace amounts of disseminated cinnabar (Duschak \& Schuette, 1925) in the wallrock along the north-south structure (Figure 3). Craddock (1995) also indicates that Bronze Age miners in Europe were similarly thorough "....and removed every last morsel of ore before a working was abandoned."

Occurrence of the mercury in association with the sedimentary rocks at Azogues is somewhat similar to the geologic setting of Almadén, Spain where the ore is also stratabound, disseminated cinnabar with some native mercury. The geochemical signature at Azogues is much like the geochemical signature at Almadén and Huancavelica (Rytuba, 1986; Noble \& Vidal, 1990) and includes As (9 - $75 \mathrm{ppm}), \mathrm{Sb}$ (10 - $54 \mathrm{ppm})$, and other elements of interest such as $\mathrm{Ag}$ (0.3 $2.4 \mathrm{ppm})$ and $\mathrm{Pb}(12-220 \mathrm{ppm})$. Background elemental concentration for sandstones is also provided on Table 1 . The amount of sulfur (182 - $7262 \mathrm{ppm}$ ) may be related to the sulfur held in cinnabar; however, other sulfur-bearing minerals may be present. Altered rhyolite was found at one location (Table 1, sample 
EC164 with $113 \mathrm{ppm} \mathrm{Hg}$ ); however, there is no field evidence to suggest that Azogues is a hot-spring mercury occurrence.

\section{History of Retorting and Ancient Industrial Uses}

Retorting cinnabar to obtain mercury dates to 8,000 years ago in ancient Turkey where the $3 \mathrm{~m}$ marble base of an ancient retort was found. The metal would have been used for gilding and alluvial gold amalgamation (Barnes \& Bailey, 1972; Brooks et al. 2017). Fine-grained gold from the Takht-e Soleyman mining district, northwest Iran, was first panned and then mixed with mercury for retorting (Momenzadeh et al., 2016). And, also in Mesopotamia, ancient cinnabar processing on a smaller scale is indicated by the Tepe Gawra pot (3500 BC) that has been interpreted as an ancient mercury retort (Levey, 1955).

The earliest written description of mercury used for alluvial gold mining was by al-Biruni, an $11^{\text {th }}$ century Persian scientist. Small pits in the Sind (Indus) Riverbed were filled with mercury; the mercury amalgamated the alluvial gold flakes and then the mercury-gold amalgam was recovered, squeezed in a cloth to remove most of the mercury, and then the amalgam "nugget" was burned to volatilize any remaining mercury (al-Hassan \& Hill, 1986). This anthropogenic gold "nugget" could then be fashioned into jewelry or hammered to produce gold foil.

In Europe, Agricola (1556/1912) indicates that the use of mercury for gold amalgamation dates at least to Roman times, whereas the use of mercury for silver amalgamation dates only to the $16^{\text {th }}$ century. This chronology is consistent with the onset of the use of mercury from Huancavelica, Perú and mercury imported from Almadén, Spain for silver amalgamation, specifically the Patio Process, during Colonial time in the New World (Barba, 1640/1923; Crozier, 1993; Robins, 2011).

In Perú, ancient retorting is indicated by ceramic retorts (hornos antiguos) that date to AD1400 that were found near the Huancavelica mines (Rivero \& Tschudi, 1851 in Petersen, 1970/2010). Therefore, retorting cinnabar and the end-uses of the mercury in the ancient Andes, whether from Huancavelica, Azogues, or any of a number of other mercury occurrences, are thoughtprovoking. And, given the availability of cinnabar and the amount of gold masks, pectorals, and other gold artifacts that were produced before the arrival of the Europeans, then retorting of cinnabar and amalgamation are consistent with any discussion of ancient gold mining and artifact production in the Andes. The mercury produced from the ancient Huancavelica retorts would have had but one use-much as mercury is widely used today-for small-scale alluvial gold mining (Cabrera La Rosa, 1954; Larco Hoyle, 2001; Sandoval, 2001; Cánepa, 2005; Brooks et al. 2013).

\section{Human Health}

In Perú, Garcilaso de la Vega (1539-1616) commented that mercury fumes were 
unhealthy and inhalation resulted in "shakes" and loss of other senses (Brown, 2001; Larco Hoyle, 2001)-this observation regarding mercury and human health is very important. The implications are straightforward and provide evidence of 3 possible ways in which the ancient Andean miners and metallurgists would have been exposed to mercury fumes:

1) during ancient cinnabar mining and fire setting-Similar to Garcilaso de la Vega's observations in Perú, modern cinnabar mining at Almadén exposed workers to mercury dust and fumes that affected the nervous system (Putman, 1972). However, because of the smoke, dust, fire, heat, toxic fumes, and sulfurous smell resulting from the ancient method of fire setting, the mine would have been evacuated (Craddock, 1995). The cinnabar recovered from this process would have had two industrial uses: 1) sorted and ground for use as a pigment, or 2) retorted to provide mercury.

2) during ancient cinnabar retorting-Agricola (1556/1912) showed racks of ceramic retorts being fired and also warned of the adverse health effects of breathing the sweet-smelling mercury fumes that were released during retorting. When cinnabar is retorted, the metallic bonds between mercury and sulfur are irreversibly broken and do not recombine to precipitate as cinnabar. Therefore, in the retort in the presence of oxygen, the products would have been sulfur dioxide (gas) and mercury vapor that would have been cooled, condensed, and collected as liquid mercury (Roskill, 1990), as in the following reaction:

$$
\mathrm{HgS}+\mathrm{O}_{2}=\mathrm{SO}_{2}+\mathrm{Hg} \text { (Duschak \& Schuette, 1925). }
$$

However, owing to the imperfections in the ancient ceramics or in the seals between the ceramic vessels, then this process would have released $\mathrm{Hg}$ fumes, along with $\mathrm{SO}_{2}$, from the retorts or up the chimney (Brooks et al. 2017). Any of the pink- to light-red calcined material resulting from retorting may have been plowed under, covered by jungle growth, debris flows, or removed by rainfall. Retorting would have provided mercury to be used for ancient small-scale alluvial gold mining.

3) or from burning (refogado) the gold-mercury amalgam-in order to part the alluvial gold from the mercury-gold amalgam "nugget", the "nugget" was burned (refogado) with a blowpipe (soplete), or in modern times, with a gas torch. This burn would have released dark mercury fumes that modern miners and gold dealers in Madre de Dios or southern coastal Perú, for example, rigidly avoid during amalgam burning (Cánepa, 2005). A Benzoni sketch from the 1500s (Petersen, 1970/2010) shows that their "sopletes" are above the flames. This would have concentrated and provided higher oxygen content, which in turn provided the higher temperatures necessary to volatilize the remaining mercury and melt the gold $\left(1063^{\circ} \mathrm{C}\right)$, much as an analytical blowpipe was used for mineral analysis in the $1700-1800$ s. This analytical technique, which dates to $1500 \mathrm{BC}$ and was used by Egyptian goldsmiths, was widely used for analytical chemistry of minerals through the mid-1800s (Dana \& Ford, 1922; Jensen, 1986). The Benzoni sketch shows how the workers would have been exposed to the 
fumes during the refogado process. And, most of the approximately 2 kilograms of mercury required to produce 1 kilogram of gold (Roskill, 1990; Cánepa, 2005) would have been released, as toxic fumes, during the refogado process (Brooks et al., 2007; 2013).

Fuel for retorting would have been supplied from the abundant eucalyptus trees in the region or possibly from lignite in the Cuenca-Azogues-Biblian region (O’Rourke, 1978; Weaver \& Wood, 1994; Hackley \& Brooks, 2006).

\section{Conclusion}

Cinnabar and mercury were known and used for only two purposes in the pre-Columbian Andes and mercury was essential to Colonial silver processing. Therefore, site visits, geochemical sampling, and assessment of the cinnabar occurrences in the Andean region, such as Azogues, are important to understand the availability of cinnabar and mercury for ancient industrial applications that included: 1) pigment production, and 2) retorting cinnabar to obtain mercury for small-scale gold production. Geochemical sampling, combined with information from published documents, unequivocally indicated the availability of cinnabar and mercury at Azogues (Loma Guashon). The number of shallow workings and geometry of the Azogues adits combined with the lack of stone entrance architecture and other physical evidence at Azogues are consistent with initial pre-contact cinnabar mining for ancient industrial uses such as vermilion production and mercury retorting. However, the absence of Colonial entrance architecture indicates that it was unlikely that the Azogues occurrence was a significant source of Colonial cinnabar.

\section{Acknowledgements}

Sincere thanks are expressed to Dr. Karen Olsen Bruhns, Berkeley, CA for introducing me to the Azogues cinnabar occurrence, her colleagues in Cuenca, and for collaboration in the field during the site visit.

\section{References}

Agricola (1556/1912). De Re Metallica (638 p.). Translation by Hoover, H. C., \& H. L. Hoover, NY: Kessinger Publishing.

Ahlfeld, F., \& Schneider-Scherbina, A. (1964). Los Yacimientos Minerales y de Hidrocarburos de Bolivia [Mineral Deposits and Petroleum Occurrences of Bolivia] (388 p.): Ministerio de Minas y Petroleo, Departamento Nacional de Geologia, La Paz, Boletin 5, Especial.

al-Hassan, A. Y., \& Hill, D. R. (1986). Islamic Technology, an Illustrated History (304 p.). Cambridge University Press.

Alpers, C. N., Hunerlach, M. P., May, J. T., \& Hothem, R. L. (2005). Mercury Contamination from Historical Gold Mining in California. US Geological Survey Fact Sheet 2005-3014. https://pubs.usgs.gov/fs/2005/3014

Arana, P. P. (1901). Las Minas de Azogue del Perú [Mercury Mines of Perú] (109 p.). Lima: Imprenta El Lucero. 
Archivo General de Indias (1799). Plan del Cerro Mineral de Azogue Nombrado Guazun, Distante 4 1/4 Leguas de la Ciudad de Cuenca Según lo mas Correcta Observación, Formado de Orden del Sr. Governador Yntendente D. José Antonio de Vallejo [Map of the Azogues Mining Area, Some 4 1/4 Leagues from the City of Cuenca, According to the Most Correct Estimation, under the Order of the Gov. D. José Antonio de Vallejo]: Archivo General de Indias, MP-PANAMA, 225-1-imagen núm. 1/1.

Azogues (1968). Azogues Topographic Map CT-NV-E1-3885-IV, Serie J721, Provincia de Cañar, Ecuador, Scale 1:50000

Báez, N. E. (2014). Explotación de Oro Aluvial en el Ecuador [Exploitation of Alluvial Gold in Ecuador] (405 p.). Quito: Univ. Central de Ecuador, Facultad de Ingeniería.

Barba, A. A. (1640/1923). El Arte de los Metales [The Art of Metallurgy] (288 p.) Trans. by Douglass, R. E., \& Mathewson, E. P., New York: John Wiley \& Sons.

Barnes, J. W., \& Bailey, E. H. (1972). Turkey's Major Mercury Mine Today and How It Was Mined 8000 Years Ago. World Mining, 25, 49-55.

Bennett, E. (1948). Almadén, World's Greatest Mercury Mine. Mining and Metallurgy, American Institute of Mining and Metallurgical Engineers, 29, 6-9.

Berger, R. L., Lane, K. E., \& Cooke, C. A. (2016). Ecuadorian Cinnabar and the Prehispanic Trade in Vermilion Pigment, Viable Hypothesis or Red Herring? Latin American Antiquity, 27, 22-35. https://doi.org/10.7183/1045-6635.27.1.22

Boyle, R. W. (1979). The Geochemistry of Gold and Its Deposits. Canadian Geological Survey Bulletin, 280, 584 p.

Brooks, W. E. (2014). Colombia Mercury Inventory 2011. Geología Colombiana, 37, Univ. Nacional, Bogotá, Colombia, 15-50.

Brooks, W. E., Ozturk, H., \& Cansu, Z. (2017). Amalgamation and Small-Scale Gold Mining at Ancient Sardis, Turkey. Archaeological Discovery, 5, 42-59.

https://doi.org/10.4236/ad.2017.51003

Brooks, W. E., Piminchumo, V., Suarez, H., Jackson, J. C., \& McGeehin, J. P. (2008). Mineral Pigments from Huaca Tacaynamo, Chan Chan, Northern Peru. Bulletin de I'Institut Francais d'Études Andines, Lima, 37, 1-10.

Brooks, W. E., Sandoval, E., Yepez, M., \& Howard, H. (2007). Peru Mercury Inventory 2006. US Geological Survey Open-File Report 2007-1252.

http://pubs.usgs.gov/of/2007/1252/

Brooks, W. E., Schwörbel, G., \& Castillo, L. E. (2013). Amalgamation and Small-Scale Gold Mining in the Ancient Andes. In N. Tripcevich, \& K. J. Vaughan (Eds.), Mining and Quarrying in the Ancient Andes. Interdisciplinary Contributions to Archaeology (pp. 213-229, Ch. 10). New York, NY: Springer Publishing.

https://doi.org/10.1007/978-1-4614-5200-3_10

Brown, K. W. (2001). Workers' Health and Colonial Mercury Mining at Huancavelica, Peru. The Americas, 57, 467-496. https://doi.org/10.1353/tam.2001.0030

Cabrera La Rosa, A. (1954). Asimismo, es possible suponer que los peruanos de aquellas tierras conocián, ya en épocas remotas, el método de la amalgamación, empleando para ello el azogue que lograban obtener del cinabrio cuyas menas existián en Buldibuyo: Situación Actual de la Minería del Mercurio en el Perú. [Therefore, It Is Possible That the Peruvians from Those Areas Knew, in Ancient Time, the Method of Amalgamation, using Azogue/Mercury That Was Obtained from Cinnabar Ores at Buldibuyo: Overview of mercury mining in Perú.] Minería y Metalurgia, Madrid, 3-12.

Cánepa, C. (2005). Minería a Pequeña Escala en la Costa Sur Media del Perú. [Small Scale Mining in Southern Coastal Perú (79 p.)] Lima: Instituto Geológico Minero y Me- 
talúrgico, Boletín 3.

Cárdenas, M. N. (1990). Investigación Histórica de la Minería en el Ecuador. [Investigation of Historic Mining in Ecuador (450 p.)] Quito: Dirección de Industrias del Ejercito.

Carrión Mero, P. C., Herrera Franco, G., Berrezueta Alvarado, E., \& Domingues, M. J. (2011). Ruta del Oro en Ecuador, Proyeccion de Polo de Desarrollo. [The Gold Trail in Ecuador, Overview and Development.] In H. Villegas Vega (Ed.), XIV Congreso Latinoamericano de Geología y XIII Congreso Colombiano de Geologia (p. 315).

Chacon Zhapán, J. (1986). Historia de la Minería en Cuenca. [History of Mining in Cuenca (110 p.)] Cuenca: Universidad de Cuenca, Instituto de Investigaciones Sociales.

Craddock, P. T. (1995). Early Metal Mining and Production (363 p.). Washington DC: Smithsonian Institution Press.

Crozier, R. D. (1993). Silver Processing in Spanish America, the Patio and Buytron Processes. Canadian Mining and Metallurgical Bulletin, 86, 86-91.

Dana, E. S., \& Ford, W. E. (1922). A Textbook of Mineralogy (360 p.). New York, NY: Wiley \& Sons.

Delbridge, C. G., \& Robertson, A. (1992). Ecuador Mineral Industry Profile (12 p.). London: Delbridge-Robertson Associates Consultant Report.

Duschak, L. H., \& Schuette, C. N. (1925). The Metallurgy of Quicksilver (168 p.). US Bureau of Mines Bulletin 222.

Egüez, A. (1993a). Mapa Geológico de la Republica del Ecuador. [Geologic Map of the Republic of Ecuador.J CODIGEM-BGS, Gobierno de Ecuador, Scale 1:1,000,000.

Egüez, A. (1993b). Mapa Tectono-Metalogénico de la Republica del Ecuador. [Tectono-Metallogenic Map of the Republic of Ecuador.] CODIGEM-BGS, Gobierno de Ecuador, Scale 1:1,000,000.

Gemuts, I. (1992). Gold Deposits of Southern Ecuador (Vol. 11, pp. 1-13). Society of Economic Geologists Newsletter.

Gurmendi, A. (2012). Peru Minerals Yearbook 2011. US Geological Survey Minerals Yearbook. https://minerals.usgs.gov/minerals/pubs/country/2011/myb3-2011-pe.pdf

Hackley, P. C., \& Brooks, W. E. (2006). World Coal Quality Inventory, Bolivia, Ecuador, Paraguay, and Uruguay. In A. W. Karlsen, S. J. Tewalt, \& R. B. Finkelman (Eds.), World Coal Quality Inventory, South America (Chapter 8). US Geological Survey of 2006-1241.

Hall, R. B., \& Feininger, T. (1970). Mineral Resources of Parts of the Departments of Antioquia and Caldas, Zona II, Colombia (160 p.). US Geological Survey Open-File Report 1970-0148.

Holloway, H. L. (1932). Gold in Ecuador. Mining Magazine, 46, 219-223.

Howell International (2014). Mines of South America. Castle Rock, CO: Howell International Enterprises, LLC.

Jensen, W. B. (1986). The Development of Blowpipe Analysis (pp. 123-149). New York, NY: The History and Preservation of Scientific Instruments, Rochester.

https://doi.org/10.1007/978-94-009-4690-3_11

Kaufmann Doig, F. (1978). Manual de Arqueologia Peruana. [Manual of Peruvian Archaeology (800 p.).] Lima.

Kiefer, A. M., Drace, K., Seney, C. S., \& Viega, M. (2015). Challenges Associated with Using Retorts to Limit Mercury Exposure in Artisanal and Small-Scale Gold Mining, Case Studies from Mozambique, Ecuador, and Guyana. In T. Benvenuto (Ed.), American 
Chemical Society Symposium Series (Ch. 3, pp. 51-78). Washington DC.

Larco Hoyle, R. (2001). The Moche (Vol. 2, 350 p.). Lima: Museo Arqueologico Rafael Larco Herrera, Pueblo Libre.

Levey, M. (1955). Evidence of Ancient Distillation, Sublimation and Extraction in Mesopotamia. Centaurus, 4, 23-33.

https://doi.org/10.1111/j.1600-0498.1955.tb00466.x

Lleres Pérez, R. (2015). Metallurgy in Ancient Ecuador (210 p.). Oxford: Archaeopress Publishing, Pre-Columbian Archaeology 5.

McAllister, J. F., Flores, H., \& Ruiz, C. (1950). Quicksilver Deposits of Chile (pp. 361-400). US Geological Survey Bulletin 964-E.

Momenzadeh, M., Nezafati, N., Sarraf, M. R., \& Shabani, K. (2016). Ancient Gold-Mercury Mining in the Takht-e Soleyman Area, Northwest Iran. Metalla, 22, 147-168.

Morer, J. J., \& Nicholls, E. (1962). Informe de la Mina El Socorro Mercurio, Municipio de Aguadas, Departamento de Caldas. [Report on the El Socorro Mercury Mine, Aguadas, Caldas Department.] Servicio Geologico Nacional, Boletin Geologíco, 10, 217-228.

Mutis Jurardo, V. (1983). Catalogo de los Yacimientos, Prospectos y Manifestaciones Minerales de Colombia, Mercurio. [Catalog of Mineral Occurrences of Colombia, Mercury.] Publicaciones Geológicas Especiales del Ingeominas, 13, 203-207.

Noble, D. C., \& Vidal, C. E. (1990). Association of Silver with Mercury, Arsenic, Antimony, and Carbonaceous Material at the Huancavelica District, Peru. Economic Geology, 85, 1645-1650. https://doi.org/10.2113/gsecongeo.85.7.1645

O’Rourke, J. E. (1978). Coal Basins of Ecuador. In F. E. Kottlowski, A. T. Cross, \& A. A. Meyerhoff (Eds.), Coal Resources of the Americas-Selected Papers (pp. 43-60). Geological Society of America Special Paper 179.

https://doi.org/10.1130/SPE179-p43

Petersen, G. (1970/2010). Mining and Metallurgy in Ancient Peru (97 p.). Trans. by W.E. Brooks of Minería y Metalurgia en el Antiguo Perú, 1970, Arqueologicas 12, Publicaciones del Instituto de Investigaciones Antropologícas, Museo Nacional de Antropología y Arqueología, Pueblo Libre, Lima, Perú, Geological Society of America Special Paper 467.

Putman, J. (1972). Mercury, Man's Deadly Servant. National Geographic, 142, 45-57.

Robins, N. A. (2011). Mercury, Mining, and Empire (298 p.). Bloomington: Indiana Univ. Press.

Roskill (1990). The Economics of Mercury (233 p.). London: Roskill Information Services Ltd.

Ruiz Fuller, C. (1965). Geología y Yacimientos Metalíferos de Chile. [Geology and Metal Occurrences of Chile (405 p.).] Santiago: Instituto de Investigaciones Geológicas.

Rytuba, J. J. (1986). Descriptive Model of Almaden Hg, Model 27b. In D. P. Cox, \& D. A. Singer (Eds.), Mineral Deposit Models (p. 180). US Geological Survey Bulletin 1693.

Sandoval, F. (2001). La Pequeña Minería en el Ecuador. [Small-Scale Mining in Ecuador (No. 75, 31 p.].] International Institute for Environment and Development-Mining, Minerals, and Sustainable Development.

Scheib, R. (1934). Anotaciones Sobre un Yacimiento de Cinabrio en el Tolima: Compilación de los Estudios Geológicos Oficiales en Colombia, Tomo 1. [Notes on a Cinnabar Deposit in Tolima: Compilation of Official Geologic Studies in Colombia (Vol. 1, pp. 90-96).] Bogotá: Boletines Geológicos, Servicio Geológico Colombiano. 
Singewald, Q. D. (1950). Mineral Resources of Colombia (166 p.). U.S. Geological Survey Bulletin 964B.

The Economist (2013). Mining in Ecuador, Going for Gold. The Economist, 22 June. http://www.economist.com/news/americas/21579871-brazil-raises-its-mining-royalties -ecuador-cuts-its-own-going-gold

Truhan, D. L., Burton, D. L., \& Bruhns, K. O. (2005). El Cinabrio en el Mundo Andino. [Cinnabar in the Andean World.] Revista de Antropología, 18, 193-205.

Turekian, K. K., \& Wedepohl, K. H. (1961). Distribution of the Elements in Some Major Units of the Earth's Crust. Geological Society of America Bulletin, 72, 175-192. https://doi.org/10.1130/0016-7606(1961)72[175:DOTEIS]2.0.CO;2

Valdez, F., Gratuze, B., Yepez, A., \& Hurtado, J. (2005). Evidencia Temprana de Metalurgía en la Costa Pacifica Ecuatorial. [Evidence of Early Metallurgy, Pacific Coast of Ecuador.] Bogota: Boletin Museo del Oro 53.

http://www.banrep.gov.co/museo/esp/boletin/53/v-g-y-h.htm

Vetter Parodi, L. M. (2016). Plateros y Saberes Andinos. [Silver Craftsmen and Andean Knowledge (326 p.).] Cusco: Centro de Estudios Regionales Andinos Bartolomé de las Casas, Serie Archivos de Historia Andina 5054.

Weaver, J. N., \& Wood, G. H. (1994). Coal Map of South America. US Geological Survey Coal Investigations Map C-145.

Whitaker, A. P. (1941). The Huancavelica Mercury Mine (150 p.). Cambridge, MA: Harvard University Press.

Wolf, T. (1892/1975). Geografía y geología del Ecuador. [Geography and Geology of Ecuador (798 p.).] Quito: Casa de la Cultura Ecuatoriana.

Yates, R. G., Kent, D. F., \& Concha, J. F. (1955). Geology of the Huancavelica Quicksilver District, Peru (45 p.). US Geological Survey Bulletin 975-A.

Yepez, A. (2016). Las Minas de Oro del Río Santa Bárbara en el Austro Ecuatoriano, De las Quejas Españolas Coloniales del Siglo XVII a la Ideología Prehispánica Profunda de los Pueblos Aborígenes. [The Santa Barbara Gold Mines of Southern Ecuador, Spanish Colonial Conflict with the Deep Ideologies of the Prehispanic Groups.] Dialogo Andino, 49, 397-408. 